\title{
Students' Kinesthetic Intelligence in Physical Education: Garnering Indonesian Literatures
}

\author{
Andi Imrah Dewi ${ }^{1}$, Mohammad Syahrir ${ }^{2}$, A. Ardiansyah3, Hendriana Sri \\ Rejeki4
}

DOI:10.35445/alishlah.v13i3.1440

\section{Article Info}

Keywords:

Kinesthetic intelligence;

Physical Education;

Students competence

Kata kunci:

Kecerdasan kinestetik;

Pendidikan Jasmani;

Kompetensi siswa

\section{Abstract}

The purpose of this current research was to examine studies discussing Indonesian students' kinesthetic intelligence in physical education. This study was conducted through library research. Data was collected by sorting and selecting articles published in reputable journals in the national scopes. From the search result, five articles were designated as the research data. For analyzing the data, a content analysis was used. Researchers used Campbell, Campbell \& Dickinson's (1996) concept of multiple intelligence, more precisely kinesthetic intelligence. The study's findings reveal that the Indonesian teachers still utilized traditional methods and strategies in teaching physical education subjects to improve students' kinesthetic intelligence. Moreover, the objectives of this subject were to equip students with the competencies to be physically active for a lifetime. The implication of the studies mainly discussed the importance of uplifting the quality of physical education teachers to facilitate students' kinesthetic intelligence development better. The present study also informs the possibility for future researchers to elaborate on the findings.

\begin{abstract}
Abstrak
Tujuan dari penelitian ini adalah untuk mengkaji studi yang membahas tentang kecerdasan kinestetik siswa Indonesia dalam pendidikan jasmani. Penelitian ini dilakukan melalui studi pustaka. Pengumpulan data dilakukan dengan cara memilah dan menyeleksi artikel-artikel yang diterbitkan di beberapa jurnal bereputasi nasional. Dari hasil penelusuran, lima artikel ditetapkan sebagai data penelitian. Untuk menganalisis data digunakan analisis isi. Peneliti menggunakan konsep kecerdasan majemuk Campbell, Campbell \& Dickinson (1996), lebih tepatnya kecerdasan kinestetik. Temuan penelitian mengungkapkan bahwa guru bahasa Indonesia masih menggunakan metode dan strategi tradisional dalam mengajar mata pelajaran pendidikan jasmani untuk meningkatkan kecerdasan kinestetik siswa. Selain itu, tujuan mata pelajaran ini adalah membekali peserta didik dengan kompetensi untuk aktif secara fisik seumur hidup. Implikasi dari kajian tersebut terutama membahas tentang pentingnya peningkatan kualitas guru pendidikan jasmani untuk memfasilitasi pengembangan kecerdasan kinestetik siswa lebih baik. Penelitian ini juga menginformasikan kemungkinan bagi peneliti masa depan untuk menguraikan temuan.
\end{abstract}

\footnotetext{
${ }^{1}$ Universitas Tadulako, Palu, Indonesia

Email: andiimrahdewiandi@yahoo.co.id

2 SMA I Tinombo Selatan, Sulawesi Tengah, Indonesia

3 Universitas Islam Negeri Datokarama, Palu, Indonesia

4 Universitas Tadulako, Palu, Indonesia
}

Vol.13 (3) December, 2021

Received: November 27, 2021; Received in revised form: December 25, 2021; Accepted: December 26, 2021; Available online: December 31, 2021. This is an open access article under a Creative Commons Attribution-NonCommercial-ShareAlike 4.0 International License. 


\section{INTRODUCTION}

Physical education in schools is not merely an activity to educate students through physical movements, but it is also used as a medium to solve motion problems. Lutan (2000) and Kusuma et al. (2011) argue that physical education is the school program designed to lead youngsters to a lifetime of physical activity. The goal, or purpose, of a quality physical education program is to guide youngsters in the process of becoming physically active for a lifetime. George Graham stated that physical education is a school program designed to lead children to physical activity for life. Quality physical education aims to guide children in being physically active for life. Physical education aims to achieve educational goals using physical/physical means of movement. Through this movement, educational goals will be achieved. Two of the objectives of physical education according to the National Education Standards Agency (BSNP) 2006 are: (1) developing self-management skills to develop and maintain physical fitness and lifestyle through physical activity, (2) improving the ability and skills of creative gymnastics. As mentioned earlier, physical education is a subject carried out through physical activities as the "bridge" to achieve goals. In an attempt to achieve these goals, it is necessary to have an innovative learning model. Learning models are one form of applying a system approach in learning activities that incidentally examines a systematic process that produces a learning system that is ready to be used appropriately. Before making educational innovations, a student is equipped with the modalities to carry out the learning process. Big capital for a student is an intermediary in visual, audio, and kinesthetic. According to the child's modality for learning, the types of media are grouped into kinesthetic media types.

Kinesthetic motion intelligence is one type of multiple intelligences. This theory is a new source of strength for educators to be more creative and innovate in the world of education. In addition, every educator must learn to believe that behind the limitations of students, there are also advantages that have not been explored properly. Meanwhile, kinesthetic intelligence is defined as an intelligence possessed by anyone who has the ability to use their whole body, or at least part of their body, to solve problems is a development of kinesthetic intelligence (Gardner, 1993; Yuningsih (2015). In addition, Wijayanti \& Rukiyati (2021) mention that kinesthetic intelligence is a person's ability to combine the physical and the mind to produce perfect movements. This means that kinesthetic intelligence is good coordination between the nerves (mind) and the rest of the body. It is the ability to perform good movements, such as running and movements that are done naturally, providing space for various developments, including in the form of developing creative movements with various daily activities that can be well responded to into forms (Tedjasaputra, 2001; Suherman et al., 2004). Imaginative and interesting motion in the presentation of cultural activities certainly gives each other positive energy in their lives including daily activities by walking, running, jumping and others who are responded to and try to give a touch of movement through developing motion from an existing basis then distorted properly through beautiful, broad movements so that it becomes a beautiful gymnastic movement besides that basic movements have an important role in learning physical education, especially sports such as sprinting, throwing, long jumps, high jumps, and other sports Ahmad (Brown, 2000; Poerwanti, 2011; Cahyono et al., 2011). This promotes the kinesthetic motions that support students to be more energetic and powerful.

It is the main capital for the sustainability of more complex movement abilities so that they can support daily activities; kinesthetic motion is the ability to balance physical and mental movements that are in good agreement with each other to channel the body shape of the movement and produce beautiful, energetic and powerful movements. For example, physical intelligence refers to a person's ability to use his limbs to perform movements like running or dancing, or to build something, or to create artistic works of art. Kinesthetic motion, on the other hand, relies on the body's natural ability to move. Movements are both locomotor and non-locomotor, as in rhythmic gymnastics or creative gymnastics. Students' ability to express themselves creatively is enhanced when physical education teachers incorporate kinesthetic movement into their lessons. This is a novel way of incorporating kinesthetic movement into the classroom through a fusion of culturally- 
based creative gymnastics and activities. Sports education is one of the most interesting presentations for the development of the world of sports that incorporates aspects of local culture. Kinesthetic media, as defined by Poerwanti (2011) and Turmudi (2021), necessitate physical contact between students and teachers to function properly. Games and simulations are a type of kinesthetic media in which the media is physical and includes the surrounding environment and mood. As a physical education teacher, you can expect your creativity to produce educational products that can be used by students, including different models.

From learning these skills, the students can give a good response in learning the basics of movement in a cultural activity which then develops into a beautiful and very interesting gymnastics movement through Physical Education subjects so that they can create beautiful gymnastic movements as a form of their creativity to continue to develop themselves and need to be confident in exploring Movement into innovative movements. The movement of development and in the field of health is to trigger the release of sweat from the body. If done regularly, the effect makes the body thin and increases the spirit of work and nourishes the limbs. Several observations and interviews conducted in several high school schools in Parigi Motong explained some descriptions of the not yet optimal learning of physical education in developing cultural-based kinesthetic intelligence and students' activities (Suherman, 2004). Researchers found several problems faced by both teachers and students in schools in terms of kinesthetic movement intelligence, namely physical education teachers who were less creative and less varied in teaching alias monotonous, the methods used were still conventional/traditional, students were less enthusiastic and lazy to take part in learning. However, the students' ability to perform kinesthetic movement intelligence has not been maximized, especially the creation of creative gymnastics movements which will certainly provide attractiveness and interest for students in exploring their abilities in developing movements into creative movements that have meaning and power for fitness needs and continue to prioritize creating content that contains elements of creativity and beauty as one of the main things that make students more interested.

While the researchers found some relevant research about the importance of kinesthetic intelligence in the physical education subject in Indonesia, which were mostly based on the data taken in the field, the researchers have not found the study using library research in the contexts of Indonesia yet (see Kadi, 2018; Irwansyah, 2018; Rizqi \& Sutapa, 2019). For this reason and based on the explanation above that physical education is an educational process that provides breadth to improve the quality of the whole human being, namely psychomotor, affective, and cognitive, the researchers are interested in finding out the similar issue using the literature perspective. In physical education, several materials are delivered. Physical education includes games and sports activities; development activities; self-test activities/gymnastics; rhythmic activity; aquatics (water activities; and outdoor education), and health. This material is presented to help students understand why humans move and how to move safely, efficiently, and effectively. Lastly, the researchers hope that this study can give many positive contributions, especially for the readers.

\section{METHODS}

\section{Research Design}

The researchers decided to conduct a library study to analyze the literature that discussed the students' kinesthetic intelligence in physical education in Indonesia, mainly in the young learners' contexts. This method was chosen because the study in this area was still limited and to record the existed literature as a reference for the betterment of physical education focus in future studies.

\section{Criteria of selection}

To collect the data, the researchers sorted articles from different sources. The main source that was used was Google Scholar. Several keywords were typed to search the articles. The keywords are, among others; kinesthetic intelligence, multiple intelligence, physical education, young learners' 
kinesthetic intelligence, physical education in Indonesia, physical education in elementary school, bodily-kinesthetic movement, kinesthetic activities, kinesthetic movement, kinesthetic movement intelligence. After a massive search, the researchers found five articles suitable with the kinesthetic intelligence topic in this current article. Moreover, the researchers also selected the articles published in the last five years. This aims at providing more recent and up-to-date findings and information regarding the issue of kinesthetic intelligence and physical education.

\section{Analysis Procedures}

The articles that have been garnered were analyzed using Content Analysis (Stemler, 2015). The analysis process was guided using the concept of multiple intelligence (Campbell, Campbell \& Dickinson, 2015), which was more specifically directed to the type of kinesthetic movement as one of multiple intelligences theory in it namely the activities related to physical movements such as identical games, drag-and-drop exercises, or online simulations that will engage this intelligence (Watrous-McCabe, 2005).

\section{FINDINGS AND DISCUSSION}

The researchers found out several characteristics of the studies conducted by Indonesian scholars in relation to the topic of physical education and kinesthetic intelligence. To illustrate the big picture, the following table is presented. This table explains the five articles analyzed using the Content analysis method based on Campbell, Campbell \& Dickinson's (1996) multiple intelligence framework, specifically in the kinesthetic part and sorted the activities involving physical movements in the physical education subject.

Table 1 Studies on Kinesthetic Intelligence in Physical Education

\begin{tabular}{|c|c|c|c|}
\hline Author(s) & $\begin{array}{c}\text { Year of } \\
\text { Publication }\end{array}$ & Method & Summary \\
\hline Irwansyah & 2018 & $\begin{array}{l}\text { Correlational } \\
\text { study }\end{array}$ & $\begin{array}{l}\text { There is a relationship between intelligence } \\
\text { kinesthetic, interpersonal intelligence, } \\
\text { intrapersonal intelligence with students' } \\
\text { learning outcomes. }\end{array}$ \\
\hline Kadi et al. & 2018 & $\begin{array}{l}\text { Qualitative case } \\
\text { study }\end{array}$ & $\begin{array}{l}\text { The goal of physical education in terms of } \\
\text { rhythmic gymnastics done every Friday is to } \\
\text { help the youngster develop his or her maximal } \\
\text { kinesthetic intelligence. }\end{array}$ \\
\hline Aeni et al. & 2019 & Action research & $\begin{array}{l}\text { The kinesthetic intelligence of children } \\
\text { through rhythmic gymnastics activity } \\
\text { increased very well. }\end{array}$ \\
\hline Rizqi \& Sutapa & 2019 & Survey method & $\begin{array}{l}\text { The engaging and fun kinesthetic-based } \\
\text { learning paradigm is the basic movement in a } \\
\text { succession of natural movements that may be } \\
\text { contested (circuits) and can stimulate motor } \\
\text { abilities in elementary school pupils. }\end{array}$ \\
\hline Suhadi et al. & 2020 & Mixed method & $\begin{array}{l}\text { The bodily-kinesthetic intelligence approach in } \\
\text { Physical Education did not allow students to } \\
\text { develop their physical and mental abilities to } \\
\text { their full potential. }\end{array}$ \\
\hline
\end{tabular}

Table 1 shows that Indonesian researchers have conducted studies on physical education and kinesthetic intelligence in children using different lenses of research methodologies, from quantitative, qualitative, and mixed methods. This means that various answers were also found to describe the situations in this matter. From the analysis, the researchers divide the findings into two categories, namely Regular Stimulation on Students' Kinesthetic Movements and Creative ways to Develop Students' Kinesthetic Intelligence. Besides the wrapped analysis, the researchers also highlight the pedagogical implication of this literature review. The researchers would explicate those categories and pedagogical implications in the following explanation. 


\section{Regular Stimulation on Students' Kinesthetic Movements}

In most of the literatures taken as the research data, it was informed that the repeated stimulation to develop students' kinesthetic intelligence is beneficial. This repertoire method is effective, especially for training young learners. For instance, a study conducted by Kadi et al. (2018) emphasizes that the weekly gymnastics activities can increase their ability to move more elastically. Young learners in their contexts had had increased kinesthetic performance when they attended this regular training. This activity does not only promote cooperation between students but also the collaboration among teachers. Suhadi et al. (2020) mention that teachers who have completely different areas from each other would be possible to conduct cooperation because of the activities they conduct in the classroom settings are also different. By doing such cooperation, physical education teachers will collaborate with classroom teachers to embed the importance of developing students' kinesthetic intelligence that may impact the students' classroom learning achievement. This is crucial because kinesthetic intelligence does not only influence the students' physical capability, but also their interpersonal and intrapersonal competence. To support this idea, the study of Irwansyah (2018) strengthens that there is a strong correlation between kinesthetic intelligence, intrapersonal approach, interpersonal approach, and students' learning achievement. This finding supports the previous idea that the teachers' collaboration to embed this type of intelligence in other learning activities will become a regular stimulation that can help them move flexibly.

\section{Creative ways to Develop Students' Kinesthetic Intelligence}

The second scrutiny of this literature study leads to the discovery of the importance of being creative teachers in physical education subjects. This means that teachers must be able to generate interesting circumstances that can attract students' learning interest. As a support to this statement, Rizqi \& Sutapa (2019) state that the interesting ways of teaching physical education to train students' kinesthetic competence are able to generate elementary school students' motor skills. The creative ways can be embodied in the gymnastics movement. For instance, introducing rhythmic gymnastics activities to students instead of presenting traditional gymnastics in students' physical education subjects could be an alternative solution to produce a creative teaching atmosphere. Their study was mainly directed to investigate three physical education teachers who teach in elementary schools based on the 2013 Curriculum required to practice locomotor, non-locomotor and basic manipulative movements in various forms of simple or traditional games. Similarly, Irwansyah (2008) notes that it is important to vary activities in physical education. This aims to avoid boredom in the learning process. Young learners always expect something new because they tend to easily get bored. Understanding this condition, teachers have to initiate innovation and implement it to the students. In addition, he also emphasizes that teachers must be able to give examples to the students practically. They are encouraged to order the students and practice with them all together. For example, the activities of rhythmic gymnastics that relatively have complex movements need to be introduced by teachers' examples. These activities are claimed to develop students' body coordination, balance, power, flexibility, endurance, and speed.

\section{Pedagogical Implications}

Having understood the importance of kinesthetic intelligence in supporting students' physical and mental readiness to learn other subjects, physical education teachers have pivotal roles in realizing this mission. The ability to generate interesting and innovative teaching is the first main capital that they must possess, and only critical teachers can do such a thing. However, to create such teachers, several treatments must be conducted even since they become pre-service teachers. A study conducted by Uzunos \& Demirhan (2017) suggests teaching activities to teach physical education pre-service teachers through creative drama. Their study informs that this activity has given positive contribution on developing physical education's critical thinking. This is because creative drama promotes intellectual challenges that initiate the thinking process. The employment of the critical thinking process publicized knowledge about and implementation of cognitive skills and affective components, as well as maneuvers, intricated in critical thinking. Additionally, Nista-Piccolo (2020) 
intelligently suggests that it is truly pivotal to consider the students' learning preference considering their diverse potentials. It is also suggested to emphasize physical education teaching through various approaches that can awareness of the different potential the students possess. This idea is in line with the Gardner's (1993; 2006a) multiple intelligence framework which became the foundation of Nista-Piccolo's study.

\section{CONCLUSION}

The conclusions that can be drawn from the research are the various ways of scrutiny were conducted by the Indonesian scholars utilizing diverse approach of methodology. The findings were mainly talking about the importance of varying activities in physical education subject to attract students' learning interest. As an instance, kinesthetic movement intelligence in cultural activities through creative rhythmic gymnastics is able to attract the attention of students by developing movement and floor patterns that are played to attract attention and using masks as a tool or property to comply with health procrees and beautify a good appearance, combined with costumes and accessories that are used on the head to make it look as aesthetically pleasing as possible. Based on the results of this study, the authors provide suggestions as consideration material that teachers must be more creative and effective in providing direction to students so that the physical education learning process can be varied and provide energy that can stimulate students to be more enthusiastic in participating in physical education subjects combined with a creative process. In honing special kinesthetic movements on gardening materials in creative gymnastics to improve student learning outcomes and class actions carried out, this study can be used as an alternative for teachers in increasing student interest in being creative and innovating to create or develop motion from an activity. It is admitted that this study has many limitations that need to be improved. The numbers of articles used as data were still small, therefore, it is necessary to conduct similar study with bigger data. Besides that, the content analysis conducted was not too deep. Frankly speaking, it is better to use the theory of kinesthetic intelligence specifically than taking a general framework of multiple intelligence. Thus, future researchers can find such a theory to specify the findings and discussions.

\section{REFERENCES}

Aeni, A. Q., Permanasari, A. T., \& Khosiah, S. (2019, August). Meningkatkan Kecerdasan Kinestetik Melalui Kegiatan Senam Irama. In Prosiding Seminar Nasional PG PAUD Untirta 2019 (pp. 31-40).

Asma, M. U. (2019). Nilai-Nilai Edukatif dalam pertunjukkan tari saman pada masyarakat blangkejeren Gayo Lues (Doctoral dissertation, Universitas Negeri Semarang).

Brown, D.H. (2000). Principles of language learning and teaching. Fourt Edition. San Francisco State University: Addison Wesley Longman, Inc.

BSNP. (2006) Standards of competence and basic competence in physical education, sports and health in elementary schools and madrasah Ibtidaiyah, Jakarta

Cahyono, N. (2011) "Transformation of Indonesian children's games". Article http://permatanusantara, accessed 9 February 2017

Campbell, L., Campbell, B., \& Dickinson, D. (1996). Teaching \& Learning through Multiple Intelligences. Allyn and Bacon, Simon and Schuster Education Group, 160 Gould Street, Needham Heights, MA 02194-2315 (Order No. H63373, \$27.95, plus shipping and handling)..

Gardner, H. (1993). Intelligence in seven steps. Creating the Future. Perspective on educational change, 395-406.

Gardner, H. (2006a). Multiple intelligences: new horizons. New York: Basic Books (Perseus Books Group).

Grønbæk, K., Iversen, O. S., Kortbek, K. J., Nielsen, K. R., \& Aagaard, L. (2007, September). Interactive floor support for kinesthetic interaction in children learning environments. In IFIP Conference on Human-Computer Interaction (pp. 361-375). Springer, Berlin, Heidelberg.

Hasanah, U. (2019). Penggunaan Alat Permainan Edukatif (Ape) Pada Taman Kanak-Kanak SeKota Metro. AWLADY: Jurnal Pendidikan Anak, 5(1), 20-40. 
Irianto. D. P. (2002). Basic coaching. Yogyakarta: Faculty of Sports Science, University of Horror Yogyakarta

Irwansyah, D. (2018). Analisis Kecerdasan Kinestetik, Interpersonal dan Intrapersonal dengan Hasil Belajar Pendidikan Jasmani. Journal of Education, Humaniora and Social Sciences (JEHSS), 1(1), 48-51.

Kadi, K., Halida, H., \& Yuniarni, D. (2018). Senam Irama dalam Mengembangkan Kecerdasan Kinestetik Anak Usia 5-6 Tahun di TK Karya Yosef. Jurnal Pendidikan dan Pembelajaran Khatulistiwa, $7(6)$.

Kusuma, D., Cepi Triatna \& Johar Permana. (2011). Character education in the study of theory and practice in schools. Bandung : PT Pemuda Rosdakarya.

Lengel, T., \& Kuczala, M. (Eds.). (2010). The kinesthetic classroom: Teaching and learning through movement. Corwin Press.

Lutan, R. (2000) learning motor skills, introduction to theory and methods. Jakarta: Ministry of Education and Culture

Nista-Piccolo, V. L. (2020). A closer look at the bodily-kinesthetic intelligence in Physical Education classes. Quaestio-Revista de Estudos em Educação, 22(3), 683-698.

Poerwanti. E. (2011). Development of character education assessment instruments in kindergartens. Doctoral dissertation, unpublished. Yogyakarta State University. Yogyakarta.

Rizqi, A., \& Sutapa, P. (2019, May). Teacher Competence in Developing Motor Skills of Elementary School Students. In First International Conference on Progressive Civil Society (ICONPROCS 2019) (pp. 193-195). Atlantis Press.

Stemler, S. E. (2015). Content analysis. Emerging trends in the social and behavioral sciences: An Interdisciplinary, Searchable, and Linkable Resource, 1-14.

Suhadi, S., Soegiyanto, S., Rahman, H. A., \& Sulaiman, S. (2020). Evaluation Of The BodilyKinesthetic Intelligence Model In Physical Education Teaching In Indonesia Primary School. Jurnal Cakrawala Pendidikan, 39(2), 471-479.

Suherman et al, (2004). Basic locomotor, non-locomotor and manipulative movements.

Suherman. W. S. (2004). Competency-based curriculum for physical education in theory and practice of development. Yogyakarta: Faculty of Sports Science

Tedjasaputra. (2001). Play, toys and games. Jakarta: PT. Gramedia widiasarana Indonesia.

Thambu, N., Prayitno, H. J., \& Zakaria, G. A. N. (2021). Incorporating active learning into moral education to develop multiple intelligences: A qualitative approach. Indonesian Journal on Learning and Advanced Education (IJOLAE), 3(1), 17-29.

Turmudi, E. (2021). Merajut Harmoni, Membangun Bangsa: Memahami Konflik dalam Masyarakat Indonesia. Yayasan Pustaka Obor Indonesia.

Uzunöz, F. S., \& Demirhan, G. (2017). The effect of creative drama on critical thinking in preservice physical education teachers. Thinking Skills and Creativity, 24, 164-174.

Watrous-McCabe, J. (2005, July 25). Apply multiple intelligence theory to adult online instructional design. Retrieved from http://www.learningsolutionsmag.com/articles/258/applyingmultiple-intelligence-theory-to-adult-online-instructional-design

Wijayanti, O., \& Rukiyati, R. (2021). Multiple Intelligences in Learning Musical Dramas for Prospective Primary School Teachers. JOURNAL OF TEACHING AND LEARNING IN ELEMENTARY EDUCATION (JTLEE), 4(1), 95-109.

Yuningsih, R. (2015). Peningkatan Kecerdasan kinestetik melalui pembelajaran gerak dasar tari minang. Jurnal Pendidikan Usia Dini, 9(2), 233-250. 